\title{
Karl Popper and the Method of Causal Explanation in Historical Sciences
}

\section{Jiří Stránský 1}

\begin{abstract}
The aim of this paper is to describe the method of causal explanation (or so-called "Covering Law Model") as it was developed by Karl Popper with special regard to its application in historical sciences. For this reason, the subsequent exposition takes into account also the views of Carl Gustav Hempel who was the first one to transfer this method to the field of historical sciences. It is argued that this transfer is a particular demonstration of (predominantly a Neo-positivistic) tendency to formulate a general scientific method and, therefore, an attempt to put historiography into the same category as other sciences. It is also claimed that despite this general tendency, authors like Popper or Hempel probably realize, but do not stress explicitly, that the laws that are used in historical explanations are not of the same kind and do not have the same scientific quality as laws used so-called "hard" sciences like physics for example. The paper is concluded by a brief examination of Popper's own application of this method in his historical research.
\end{abstract}

Keywords: Popper, Hempel, causal explanation, historical sciences, covering law model.

\footnotetext{
${ }^{1}$ Západočeská univerzita v Plzni, Univerzitní 2732/8, 30100 Plzeň, Czech Republic, j.stransky@seznam.cz
} 


\section{Introduction}

Karl Raimund Popper was, without any doubt, one of the most important philosophers of the $20^{\text {th }}$ century and his contribution to the field of the philosophy of science is well-known. The aim of this paper, however, is not to analyze his most influential ideas once again. What I plan to focus on instead is a quite specific problem of the method of causal explanation in historical sciences, which is just a special application of his general theory of causal explanation of an event, ${ }^{2}$ as it does not get so much attention in the secondary literature, although it is quite closely related to Popper's philosophy of science. ${ }^{3}$ In this task, I will proceed in the following way. First, I will describe Popper's method of causal explanation on a general level and examine the way how, according to his opinion, it can be applied in historical sciences. Second, I will describe a broader context of this problem and examine the debate which took place in the field of philosophy of history and philosophy of science shortly after its publication. In this section, I will also consider the possibility of Popper's changing his opinion on the given topic. Third and finally, I will raise and briefly examine the question of Popper's own application of his method in historical research.

Before we start, it should be noted that from the half of the $20^{\text {th }}$ century, the philosophy of history has faced one basic but crucial question concerning the very nature of this branch of science. The question being: should a philosopher tell historians how to do their job properly or should he or she rather just observe their actual methods and analyze them? In other words, should the nature of the philosophy of history be prescriptive or purely descriptive? Eugen Zeleňák, who has recently written an interesting article about this very topic, captures this distinction also in the terms of "top-down" or "bottom-up" approach. ${ }^{4}$ As I do not want to go into much detail here, I will limit myself to stating just two most important things which the reader should bear in mind while reading the rest of this paper. First, this distinction was clearly not exclusive to the branch of the philosophy of history but it was at that time and especially in the connection with the neo-positivistic movement present in the philosophy of science in general. Second, Popper and other authors whom I will speak about later explicitly or, in more cases, implicitly embrace the prescriptive view of the philosophy of history.

\section{The Method of Causal Explanation and Historical Sciences}

To begin our inquiry, let's turn to the topic of the method of causal explanation itself. On a general level, Popper describes it in his book The Logic of a Scientific Discovery. He says: "To give a causal explanation of an event means to deduce a statement which describes it, using as premises of the deduction one or more universal laws, together with certain singular statements, the initial conditions." ${ }^{5}$ So according to Popper, we basically have "two different kinds of statement, both of which are necessary ingredients of a complete causal explanation." ${ }^{6}$ The singular statements (or the initial conditions) on the one hand and the universal statements or universal laws of nature on the other and from these, we deduce the event which is to be

\footnotetext{
2 Donagan, Historical Explanation: The Popper-Hempel Theory Reconsidered, p. 3.

${ }^{3}$ It should be noted that this relative lack of interest is easily understandable as Popper does not elaborate on this topic explicitly in any of his works. The present research is, therefore, based on several rather brief but relevant remarks which I have selected and put together.
}

${ }^{4}$ Viz Zeleňák, Filozofia histórie medzi predpisovaním a opisovaním, pp. 356-359.

${ }^{5}$ Popper, The Logic of Scientific Discovery, p. 38.

${ }^{6}$ Ibid. 
explained. Although this method was originally devised for sciences like physics, it has later been transferred to the field of historical sciences as well. But it has to be noted that this transfer was not done by Popper himself but by Carl Gustav Hempel in his study The Function of General Laws in History (published in 1942, eight years after Popper's seminal work). ${ }^{7}$

Hempel, first of all, stresses the empirical character of a general law when he defines it as "a statement of universal conditional form which is capable of being confirmed or disconfirmed by suitable empirical findings". ${ }^{8}$ But more importantly, he explicitly claims that the function of general laws is the same in historiography as in natural sciences and that a causal explanation of any historical event has to be based on them. In other words, every singular historical event (if it is to be scientifically explained) has to be deduced, according to Hempel, from a combination of universal laws and singular statements describing the initial conditions. To quote him again: "Now the assertion that a set of events [...] have caused the event [E which is] to be explained, amounts to the statement that, according to certain general laws, a set of events of the kinds mentioned is regularly accompanied by an event of kind E." "This theory has sometimes been labelled as the "Popper-Hempel Theory", but more usually as a "Covering Law Model", a term first used by William Dray in his study Explanatory Narrative in History (published in 1954). ${ }^{10}$

To illustrate the method of causal explanation, Hempel gives an example of cracking of an automobile radiator during a cold night. ${ }^{11}$ According to him, it is not sufficient to state the initial conditions (i.e. the cold temperature) if we want to explain the outcome (i.e. the cracking of the radiator) scientifically. What we need to do is to connect these singular statements by means of one or more relevant universal laws. In this particular case, we have to know, for example, that water freezes at a certain temperature, that it changes its volume, etc.

It seems to me that the main intention of this theory is to formulate a universal scientific method of causal explanation of particular events and, therefore, to integrate historiography into the same category as other sciences. According to Maurice Mandelbaum, this can be rightly considered as an attempt to overcome the traditional neo-Kantian distinction between nomothetic sciences which explain repeatable events with the help of universal laws and idiographic sciences which explain singular events and do not make any appeal to universal laws because this distinction leads to the conclusion that there is a substantial difference between historiography and sciences like physics for example. ${ }^{12}$ It is a fact that after the introduction of the Covering Law Model this distinction ceased to be acceptable in its original form and had to be refined.

Popper himself tackles this issue again in The Poverty of Historicism and in the closing chapter of The Open Society and Its Enemies. On a general level of the philosophy of science, his position remains the same as in The Logic of Scientific Discovery but he is now also paying attention to the specific case of historical sciences. In The Poverty of Historicism, he holds the

\footnotetext{
7 It has to be noted that everything which is said in this paper about Hempel's theory is based exclusively on this relatively early study and does not take into account any of Hempel's later modifications of it.

${ }^{8}$ Hempel, The Function of General Laws in History, p. 35.

9 Ibid., p. 36.

10 Dray, Explanatory Narrative in History, p. 16.

${ }^{11}$ Hempel, The Function of General Laws in History, p. 36.

12 Mandelbaum, Historical Explanation: The Problem of ,Covering Laws', p. 231.
} 
well-known teaching about the unity of method of both natural and social sciences ${ }^{13}$ but he also claims that the main focus of historical sciences is a bit different from the focus of theoretical sciences. In physics, for example, our main interest lies in uncovering the universal laws while in the historical sciences the universal laws are usually given and we endeavour to explain the singular events. ${ }^{14}$ Let me quote an example used by Popper. If we are to explain the death of Giordano Bruno by burning at stake, we appeal, for example, to the universal law according to which every living being dies when exposed to excessive heat. But at the same time, we do not consider it necessary to mention this law explicitly in our explanation. Rather, we silently assume it as it does not lie in the main focus of our interest. ${ }^{15}$

Let's reflect for a while on this particular example because at a first sight it may rather conceal, instead of clarifying, what is meant by a causal explanation in historical sciences. It is especially striking as it does not look like a historical explanation at all (if we want to understand the causes of the death of Giordano Bruno we are not satisfied if we are told that he died because he was tied to a burning stake), ${ }^{16}$ and yet it is the only example of historical explanation that Popper provides in The Poverty of Historicism. We may understand his choice better if we look once again into The Logic of Scientific Discovery. Popper here says explicitly that the laws that are needed for any causal explanation have the character of the universal laws of nature, i.e. laws of physics. ${ }^{17}$ In The Poverty of Historicism, he does not further elaborate on the topic of the causal explanation in historical sciences but at the same time, he probably wants to show that his theory is valid not only in relation to phenomena that we can subject to actual experiment ${ }^{18}$ but to events of the past as well. In other words, he probably wants to integrate historiography into the same category as other sciences, as I have claimed earlier. So it seems only natural that he uses precisely the same form of a causal explanation with the same kind of law and simply applies it to a different (i.e. singular, historical, and unrepeatable) kind of event.

\section{Laws vs. Regularities}

If we return, however, to the above-mentioned study by Hempel we find out that he is using the notion of universal law with regard to historical (and also sociological) sciences a bit differently and in a way which we tend to regard as more appropriate. Among the laws used in this kind of explanation, he mentions, for example, the law that people who are habituated to certain skills do not welcome change, which is used in combination with other statements to explain the

\footnotetext{
${ }^{13}$ See Popper, The Poverty of Historicism, pp. 130-143.

${ }^{14}$ Ibid., p. 143-146. Cf. Donagan, Historical Explanation: The Popper-Hempel Theory Reconsidered, pp. 4-5.

${ }^{15}$ Popper, The Poverty of Historicism, p. 145.

${ }^{16}$ Cf. Donagan, Historical Explanation: The Popper-Hempel Theory Reconsidered, p. 15.

17 Popper, The Logic of Scientific Discovery, p. 38. In his earlier work, he defines the laws of nature as "universal rules that are applicable without exception and can serve as a basis for predictions"- Popper, The Two Fundamental Problems of the Theory of Knowledge, p. 86. Alan Donagan adds correctly that the strict universality of these laws is their crucial characteristics as well as their empirical falsifiability Donagan, Historical Explanation: The Popper-Hempel Theory Reconsidered, p. 4. This strict universality is not compromised even by Popper's opinion that these laws cannot be verified with absolute certainty but can only be pragmatically and temporarily corroborated. For a thorough discussion of the problem of laws of nature in Popper's philosophy, see Paitlová, Problém statusu prírodních zákonů v Popperově rané teorii poznání, esp. pp. 2-5, 9-13.
}

${ }^{18} \mathrm{Cf}$. his example of breaking of a thread when loaded with excessive weight - Popper, The Logic of Scientific Discovery, p. 38. 
claim that the tendency of government agencies is to perpetuate themselves and to expand. ${ }^{19} \mathrm{It}$ is quite obvious that this approach significantly differs from Popper's one as presented above. Hempel, without any doubt, comes closer to what we tend to regard as a proper explanation of a given historical event but to do this he has to sacrifice, at least to a certain extent, the strictly scientific character of the method of causal explanation which Popper endeavoured to keep. It is evident that his "laws" do not possess the same scientific quality as Popper's laws of nature or laws of physics. In this respect, it also becomes significant that Hempel operates not only with the notion of universal law but with notions like general regularities as well. ${ }^{20}$

Popper is touching on this issue again in the closing chapter of The Open Society and Its Enemies. Although he does not discuss it explicitly, it seems that he is now tacitly embracing a similar view as Hempel because he is now also talking about some sociological laws or psychological generalizations and not only about laws. ${ }^{21}$ It is, therefore, my contention that there is a shift between Popper's view in The Poverty of Historicism and The Open Society and Its Enemies and that it can be clearly seen on the example which he now provides. He says: "If we explain, for example, the first division of Poland in 1772 by pointing out that it could not possibly resist the combined power of Russia, Prussia, and Austria, then we are tacitly using some trivial universal law such as: "If of two armies which are about equally well armed and led, one has a tremendous superiority in men, then the other never wins." . 22 What do we have here are not strictly universal laws of physics which dictate, for example, that every living being necessarily dies when exposed to excessive heat but rather some generalizations which are undoubtedly true in most cases but not necessarily in all of them. ${ }^{23}$

But it seems to me that both Popper and Hempel fail to articulate this difference clearly and explicitly enough. As far as I am concerned, it has to be stressed that the scientific quality of these regularities is not the same as the laws of physics. So we should insist, given that we embrace the covering law model and its application in historiography, that the difference between theoretical and historical sciences should be sought not only in the different focus of interest (as Popper claims explicitly) ${ }^{24}$ but also in a difference of character of the general

\footnotetext{
19 Hempel, The Function of General Laws in History, p. 40.

20 Ibid. Cf. Jefferson, Toward Laws in History: Carl G. Hempel and the Evidence Dilemma, pp. 41-44. The notion of a scientific quality can, in this context, be defined as a degree of reliability of predictions that are based on a given general hypothesis. Predictions based on the laws of physics undoubtedly have a significantly higher degree of reliability than predictions based on, for example, some psychological or sociological regularities and, therefore, it can be said that also the explanations which employ laws of physics have a significantly higher scientific quality than the ones which employ those regularities instead. From a different perspective, we can also say that the laws of physics are strictly universal while the regularities are not (cf. $n .16$ above).
}

${ }^{21}$ Popper, The Open Society and Its Enemies II, pp. 251-252.

22 Ibid., p. 251.

${ }^{23}$ We can, for example, easily imagine a case when the bigger army is struck by some disease or natural phenomenon and so ends up losing the battle which it has been expected to win. So it is most probably true that "[...] if the covering law thesis be true, then no historian has yet succeeded in providing a genuine historical explanation." - Donagan, Historical Explanation: The Popper-Hempel Theory Reconsidered, p. 14.

${ }^{24}$ Popper, The Open Society and Its Enemies II, p. 250, The Poverty of Historicism, pp. 144-146. At this place, it should also be noted that Popper brings attention to one more possible difference between theoretical and historical sciences. According to him, in theoretical sciences, the universal laws themselves create the point of view from which we approach the subject matter of our inquiry. In historiography, on the contrary, it is us who choose the point of view deliberately. To quote Popper, we 
hypotheses that both of them are using (i.e. laws or regularities) and, accordingly, in a different scientific quality of theoretical sciences on the one hand and historical sciences on the other. This is, however, something which is rather implicit in the works of both authors and not particularly elaborated. ${ }^{25}$

\section{The Open Society}

In the last part of this paper, I will very briefly explore the way Popper himself uses his method in The Open Society and Its Enemies. ${ }^{26}$ As is well known, Popper here engages with teachings of some prominent thinkers of Western philosophical tradition whom he deems guilty of historicism ${ }^{27}$ and totalitarian tendencies. He begins his book with a short commentary on Heraclitus and a very long one on Plato, so let's find out what, according to Popper, do these two philosophers have in common and what is a distinctive trait of his interpretation of their thought. At present, I would like to stress just one thing which is rather uncommon these days in the field of history of philosophy. What I have in mind is Popper's reliance on the importance of the circumstances in which these thinkers lived and of their personal fortunes or, more often, misfortunes. With the help of this information, Popper consequently tries to explain some basic features of their philosophies.

So, as for Heraclitus, Popper writes, for example, that he has no doubt that his discoveries were "impressed upon [him] by terrifying personal experiences suffered as a result of the social and political disturbances of his day." ${ }^{28}$ As for Plato, Popper's basic strategy is the same. He begins by claiming that Plato "lived in a period of wars and political strife" and that he "suffered deeply from the instability and the lack of security in the political life of his time". ${ }^{29}$ For this reason, he allegedly believed that all social change was degeneration and so he strived to arrest all changes $^{30}$ and as a result, he developed his theory of unchangeable ideas and a political ideal

have to "consciously introduce a preconceived selective point of view into one's history; that is, to write that history which interests us." - Popper, The Poverty of Historicism, p. 150.

${ }^{25}$ It is possible, nevertheless, that Popper could have been aware of this difference because at one place he writes that while The Poverty of Historicism is a systematic analysis which aims at scientific status, The Open Society and Its Enemies does not. - Popper, The Open Society and Its Enemies I, $p$. 3. A possible explanation of this statement can be that The Open Society and Its Enemies is (unlike The Poverty of Historicism) at least partly a book of historical research. I say partly because what Popper does in this book is without any doubt also a philosophical (and maybe even philological) analysis of (mostly) Plato's text. But what he is also doing and what represents a significant aspect of The Open Society and Its Enemies is deducing the overall character of (above all) Plato's philosophy from the historical circumstances in which he lived. Taking this aspect into account, The Open Society and Its Enemies can be, in my opinion, rightly considered also as a book of historical research. For a more detailed explanation, see the next section.

${ }^{26}$ It should be noted that for a thorough investigation of the application of the method of causal explanation in The Open Society and Its Enemies a different paper would be needed. The aim of the present section is by no means to substitute such a paper. It is meant rather as a brief sketch which may be properly expanded and developed in the future.

27 "Historicism" is a term invented by Popper and defined by him as: "[...] an approach to the social sciences which assumes that historical prediction is their principal aim, and which assumes that this aim is attainable by discovering the 'rhythms' or the 'patterns', the 'laws' or the 'trends' that underlie the evolution of history." - Popper, The Poverty of Historicism, p. 3.

${ }^{28}$ Popper, The Open Society and Its Enemies I, p. 10.

${ }^{29}$ Ibid., p. 15.

30 Ibid., p. 16. 
of the arrested state. If we consider this kind of reflections and claims as a particular practical application of the covering law theory of causal explanation, we can analyze it in the following way. The particular philosophical systems are for Popper the thing which he wants to explain, the explanandum, and the personal life misfortunes the thing by which he wants to explain it, the explanans. So if I am not wrong and if Popper really applies his own method, he must also tacitly assume the existence of some general hypotheses which cover the gap between the explanandum and the explanans. We can only speculate what these are, but probably they can be for example psychological generalizations like "one's life fortunes, above anything else, are determining for one's worldview" or "philosophers strive through their philosophical systems to eliminate the misfortunes that happened to them" and so on and on. Whether Popper's interpretation of Heraclitus and Plato is sound (and whether his method bears fruit) or not, is up to every single reader to decide as the answer to this question lies beyond the scope of the present paper.

\section{Conclusion}

To conclude this paper, I just want to briefly summarize its main ideas. First of all, I endeavoured to explain the method of causal explanation of an event on a general level as it was developed by Karl Popper and, subsequently, the application of this method to the field of historical or sociological sciences which was done by Carl Gustav Hempel for the first time but, eventually, embraced by Popper as well. At the core of this method, there lies an idea that to establish a causal relation between two sorts of singular events (i.e. the initial conditions and their outcomes) one also needs some kind of general hypothesis to cover the gap between the singular statements that describe them. So according to these authors, there can be no scientific causal explanation without (at least implicit) appeal to some sort of general hypothesis.

In Popper's philosophy, however, I identified a (rather implicit) shift concerning his opinion on the character of these general hypotheses which has probably taken place sometime between writing The Poverty of Historicism and The Open Society and Its Enemies. At first, he probably wanted to put historiography on the same level as other sciences and so he thought of the covering general hypotheses in terms of universal laws of physics. It is only later that he embraces a slightly different conception and thinks of these hypotheses rather as some psychological or sociological generalizations. What I wanted to show, though, was that as Popper (and Hempel as well) does not elaborate on this topic very much, he does not articulate the important fact that while this shift in the character of the general hypotheses brings his method closer to what we tend to consider as proper to historical sciences, it also brings about a change in the scientific quality of the resulting explanation since those generalizations do not possess the strictly universal character of the laws of physics.

And, finally, in the last section, I provided just a brief outline of a possible application of this method on Popper's own historical research in The Open Society and Its Enemies. I argued that part of what Popper does in this book is deducing the overall character of the philosophy of some prominent thinkers from their life's (mis)fortunes, i.e. establishing a causal relation between these two phenomena (or more precisely the statements describing them). My claim, however, was that to be able to do this (supposing that his method of causal explanation holds true) he also has to presuppose some kind of general hypotheses which would cover the gap between them. I concluded the section by quoting a few examples from Popper's exposition and brief speculation concerning the particular general hypotheses he had to be tacitly presupposing. 


\section{References}

Donagan, A., Historical Explanation: The Popper-Hempel Theory Reconsidered, In History and Theory, Vol. 4, No. 1, 1964, pp. 3-26.

Dray, W.H., Explanatory Narrative in History, In The Philosophical Quarterly, Vol. 4, No. 14, 1954, pp. 15-27.

Hempel, C.G., The Function of General Laws in History, In The Journal of Philosophy, Vol. 39, No. 2, 1942, pp. $35-48$.

Jefferson, J., Toward Laws in History: Carl G. Hempel and the Evidence Dilemma, In Nebula, Vol. 1, No. 3, 2004, pp. 40-58.

Mandelbaum, M., Historical Explanation: The Problem of ,Covering Laws', In History and Theory, Vol. 1, No. 3, 1961, pp. 229-242.

Paitlová, J., Problém statusu př́rodních zákonů v Popperově rané teorii poznání, In Pro-Fil, Vol. 17, No. 2, 2016, pp. 2-14.

Popper, K.R.P., The Logic of Scientific Discovery. London and New York: Routledge, 2002.

Popper, K.R.P., The Open Society and Its Enemies I. The Spell of Plato. London: George Routledge \& Sons, Ltd., 1945.

Popper, K.R.P., The Open Society and Its Enemies II. The High Tide of Prophecy: Hegel, Marx, and the Aftermath. London: George Routledge \& Sons, Ltd., 1945.

Popper, K.R.P., The Poverty of Historicism. New York and Evanston: Harper \& Row Publishers, 1964.

Popper, K.R.P., The Two Fundamental Problems of the Theory of Knowledge. London and New York: Routledge, 2009.

Zeleňák, E., Filozofia histórie medzi predpisovaním a opisovaním, In Filozofia, Vol. 73, No. 5, 2018, pp. 356365 . 